\title{
PERSEPSI MASYARAKAT TERHADAP PEMANENAN AIR HUJAN DAN DAMPAKNYA TERHADAP KETAHANAN SUMBERDAYA AIR DI PULAU PRAMUKA, KEPULAUAN SERIBU, DKI JAKARTA
}

\author{
Ahmad Cahyadi dan Tommy Andryan Tivianton \\ Jurusan Geografi Lingkungan Fakultas Geografi Universitas Gadjah Mada
}

\begin{abstract}
INTISARI
Pulau kecil memiliki keterbatasan sumberdaya air terkait dengan jumlah tangkapan air hujan yang sedikit dan lensa airtanah yang rawan mengalami intrusi air laut. Salah satu sumberdaya air potensial yang dapat dimanfaatkan adalah air hujan. Pemanenan air hujan dapat dilakukan dengan menghubungkan langsung dengan bak penampungan air hujan serta dengan sumur resapan. Meskipun potensi pemanenan air hujan melalui atap di Pulau Pramuka, Kepulauan Seribu, DKI Jakarta cukup besar, masyarakat di sana cenderung untuk tidak melakukan pemanenan air hujan. Kondisi demikian berlangsung sejak didirikannya instalasi pengolahan air dengan menggunakan teknologi reverse osmosis. Selain itu, masyarakat merasa mudah dalam mendapatkan air minum kemasan yang dikirim dari Kota Jakarta. Hal di atas menyebabkan kondisi ketahanan sumberdaya air menjadi sangat rendah karena ketergantungan terhadap wilayah lain sangat besar serta ancaman terhadap kerusakan sumberdaya airtanah menjadi sangat tinggi.
\end{abstract}

Kata Kunci: Persepsi, Pemanenan Air Hujan, Ketahanan Sumberdaya Air

\section{PENDAHULUAN}

Pulau kecil memiliki keterbatasan sumberdaya air akibat karakteristik wilayahnya yang sempit dan rawan terjadi intrusi air laut (Sumawidjaja dan Suherman, 2005a; 2005b). Wilayah yang sempit (kurang dari $2.000 \mathrm{~km}^{2}$ ) menyebabkan jumlah tangkapan air hujan yang memasok airtanah memiliki jumlah sedikit (Falkland, 1991; Hehanusa dan Bakti, 2005). Selain itu, wilayahnya yang dikelilingi oleh laut menyebabkan pulau kecil memiliki kerawanan yang tinggi terhadap intrusi air laut (Cahyadi, 2012).

Hidrologi pulau kecil berbentuk lensa airtanah (Gambar 1). Ketebalan lensa airtanah sangat tergantung dari jumlah hujan yang jatuh dan meresap ke dalam tanah, jumlah penurapan airtanah, luas pulau, serta kedalaman dan arus laut di sekitar pulau kecil. Jumlah air hujan yang mampu meresap ke dalam tanah sangat dipengaruhi oleh penggunaan lahan. Perubahan penggunaan lahan dari lahan non-terbangun menjadi lahan terbangun akan menyebabkan semakin sedikitnya jumlah air hujan yang mampu meresap ke dalam airtanah. Selain itu, seringkali jumlah air hujan yang mampu meresap menjadi airtanah dipengaruhi oleh sistem drainase yang ada di suatu pulau. 


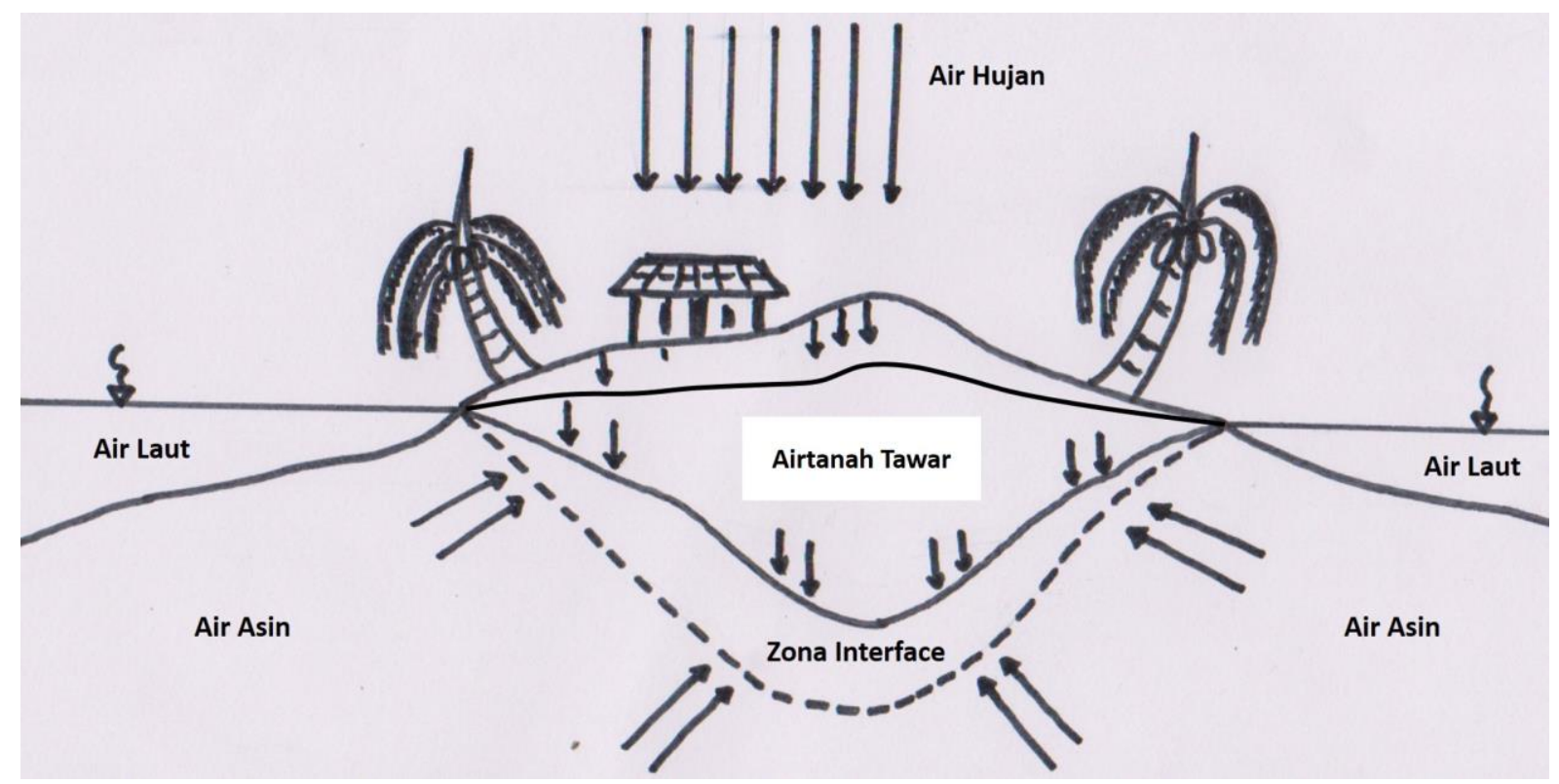

Gambar 1. Lensa Airtanah di Pulau Kecil

Meskipun memiliki jumlah sumberdaya air yang terbatas, seringkali pulau kecil di Indonesia dikembangkan menjadi lokasi wisata atau pusat pemerintahan yang menyebabkan kebutuhan air di pulau tersebut menjadi sangat tinggi, bahkan seringkali melebihi daya dukung suatu pulau kecil. Kondisi demikian kemudian dapat menyebabkan rusaknya lingkungan (Marfai dkk, 2012; Cahyadi, 2013), misalnya intrusi air laut yang semakin luas dan semakin menipisnya jumlah airtanah yang ada di pulau kecil.

Tulisan ini bertujuan untuk mengetahui persepsi masyarakat terhadap pemanenan air hujan di Pulau Pramuka. Pemanenan air hujan merupakan salah satu alternatif pemenuhan kebutuhan air bersih di pulau sangat kecil. Pengetahuan terkait dengan persepsi ini sangat pentig diketahui mengingat hal tersebut sangat menentukan berhasilnya suatu program yang akan dilakukan di masa mendatang, dalam hal ini terkait dengan pemenuhan kebutuhan air bersih di Pulau Sangat kecil. Pengetahuan tentang juga bermanfaat untuk menentukan tingkat kerentanan suatu wilayah terhadap bencana (Twigg, 2004; 2007, khususnya bencana kekerigan.

\section{PEMANENAN AIR HUJAN (RAIN WATER HARVESTING) DI PULAU PRAMUKA}

Pemanenan air hujan (rain water harvesting) adalah upaya untuk memanfaatkan air hujan yang jatuh untuk memenuhi kebutuhan air manusia dan atau tujuan konservasi. Pemanenan air hujan yang banyak dilakukan adalah dalam bentuk pemenenan air hujan melalui atap rumah yang kemudian disalurkan ke dalam bak penampung ataupun ke dalam 
sumur resapan. Pemanenan air hujan banyak dilakukan di Pulau-Pulau kecil di Indonesia termasuk di Pulau Pramuka.

Pulau Pramuka merupakan satu dari sekitar 110 pulau sangat kecil (luas kurang dari $100 \mathrm{~km}^{2}$ ) yang berkembang cukup pesat. Perkembangan yang pesat diantaranya disebabkan karena statusnya sebagai ibukota Kabupaten Kepulauan Seribu, Provinsi DKI Jakarta. Selain itu, pulau ini saat ini telah berkembang sebagai lokasi wisata (Cahyadi, 2012).

Perhitungan potensi pemanenan air hujan melalui atap rumah di Pulau Pramuka dapat dilakukan dengan mengalikan hujan wilayah di pulau tersebut dengan luas atap dengan curah hujan wilayah. Luas atap bangunan di Pulau Pramuka Tahun 2008 adaah sebesar 46,822 $\mathrm{m}^{2}$ (Gambar 2), sedangkan curah hujan wilayah adalah sebesar $1.783 \mathrm{~mm} / \mathrm{tahun}$. Berdasarkan hal tersebut, maka potensi pemanenan air hujan melalui atap bangunan di Pulau Pramuka adalah sejumlah 83.000 liter/tahun. Nilai ini dihasilkan dari hasil pengalian luas atap dengan curah hujan tahunan di Pulau Pramuka. 


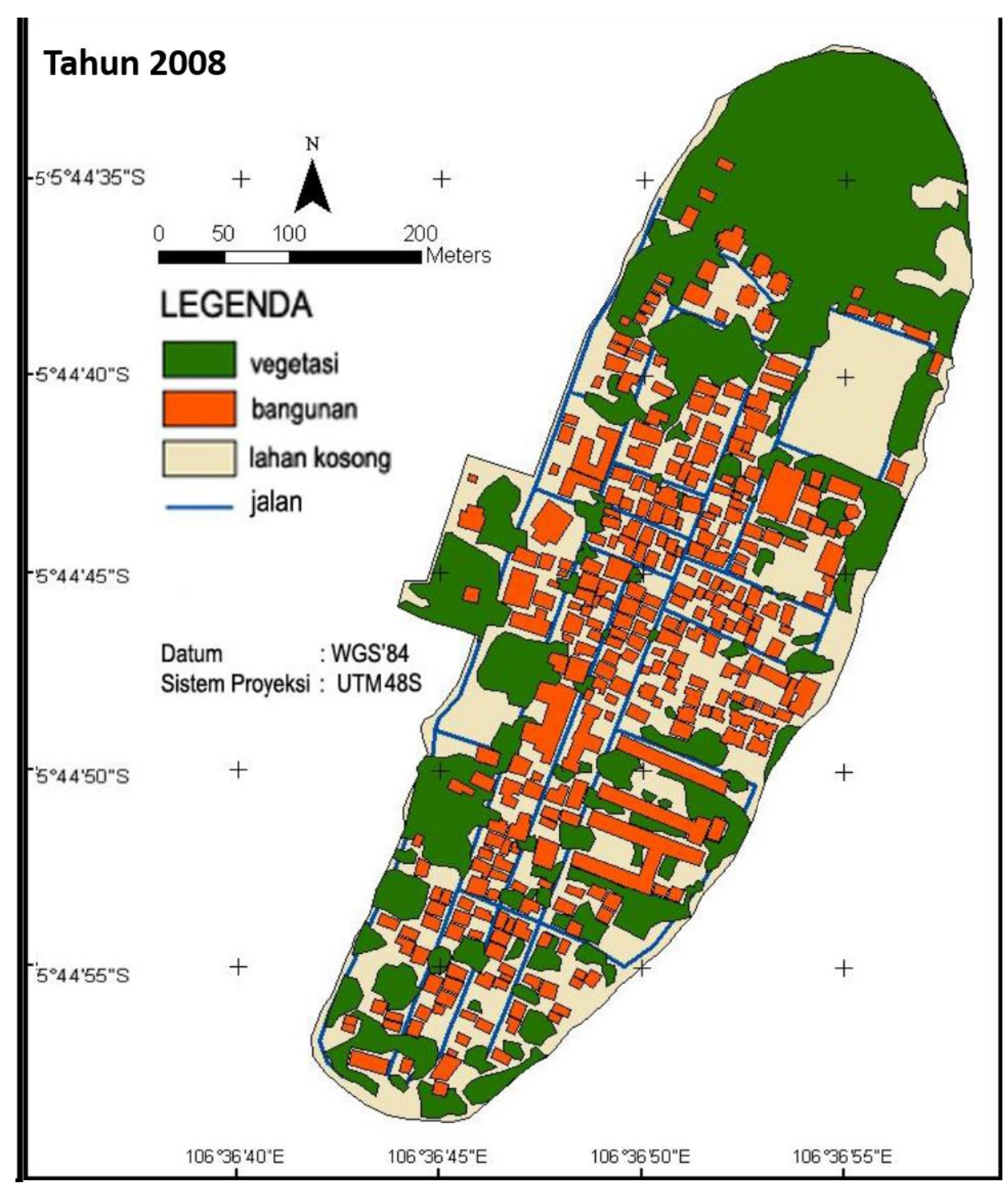

Gambar 2. Peta Penggunaan Lahan Pulau Pramuka Tahun 2008 (Wibowo, 2010)

Potensi pemanenan air hujan melalui atap rumah yang telah terhitung sebelumnya adalah potensi potensial yang ada. Hal ini karena pada kenyataannya pemanenan menggunakan atap rumah yang berbahan seng ataupun asbes dapat menyebabkan kualitas air menjadi buruk, misalnya menjadikan kandungan logam berat dan asbes dalam air (asbes bersifat karsinogenik). Oleh karena itu, upaya pemanenan hujan dengan memanfaatkan atap hendaknya dilakukan dengan mempertimbangkan jenis atap yang digunakan. Hal ini terkait dengan kualitas air yang akan di tampung atau diresapkan. 


\section{PERSEPSI MASYARAKAT TERHADAP PEMANENAN AIR HUJAN DAN DAMPAKNYA TERHADAP KETAHANAN SUMBERDAYA AIR DI PULAU PRAMUKA}

Hasil kajian dengan metode wawancara mendalam (indepth interview) menunjukkan bahwa dahulu pemanenan air hujan dengan menggunakan atap rumah dan mengalirkannya dengan tampungan air dilakukan hampir semua rumah tangga di Pulau Pramuka. Air hujan yang ditampung ini digunakan untuk memenuhi kebutuhan domestik rumah tangga. Namun demikian, airtanah tetap menjadi sumber air utama di sana.

Pemanenan air hujan dengan dalam bentuk sumur resapan, belum pernah dilakukan di Pulau Pramuka. Meskipun demikian, airtanah menjadi sumber air bersih yang dominan sejak dahulu. Pemanenan air hujan dalam bentuk sumur resapan di Pulau Pramuka terkendala dengan kedalaman muka airtanah yang sangat dangkal. Kedalaman muka airtanah di Pulau Pramuka pada musim kemarau di bagian tepi pulau memiliki kedalaman 0-60 cm, sedangkan pada bagian tengah pulau memiliki kedalaman $60-100 \mathrm{~cm}$.

Pemanenan air hujan yang pernah ada di Pulau Pramuka adalah pemanenan air hujan dengan memanfaatkan air hujan yang jatuh pada atap kemudian menampung dalam tangki tampungan air. Namun demikian, saat ini pemanenan air hujan dengan sistem ini sudah sangat sulit ditemukan di Pulau Pramuka. Hasil kajian menunjukkan bahwa masyarakat di Pulau Pramuka enggan melakukan pemanenan air hujan melalui atap rumah karena menganggap bahwa kualitas air hujan lebih buruk dibandingkan dengan kualitas air yang dihasilkan dari teknologi reverse osmosis. Selain itu, pemanfaatan air dari teknologi dianggap lebih praktis dan dianggap masih cukup terjangkau. Faktor lain yang menyebabkan pemanfaatan teknologi ini adalah karena hasil penampungan air hujan dianggap memiliki kualitas air yang kurang baik. Hal ini kemudian menyebabkan masyarakat memilih menggunakan air minum kemasan untuk memenuhi kebutuhan minum dan memasak.

\section{PENUTUP}

Persepsi masyarakat Pulau Pramuka terhadap pemanenan air hujan sangat dipengaruhi oleh kondisi lingkungan sosial yang ada di Pulau Pramuka. Masyarakat cenderung tidak memilih melakukan pemanenan air hujan karena telah terdapat teknologi yang dianggap lebih praktis dengan kualitas yang lebih baik. Namun demikian, kondisi demikian menyebabkan 
kerentanan terhadap kekurangan sumberdaya air akan sangat besar, mengingat teknologi yang digunakan dapat sewaktu-waktu rusak dan dibutuhkan waktu yang cukup lama untuk melakukan perbaikan. Selain itu, ketersediaan air minum kemasan sangat tergantung dengan kelancaran transportasi laut yang antara Pulau Pramuka dan Jakarta. Padahal, wilayah ini sering terdampak siklon tropis yang terjadi di Laut Cina Selatan (Ongkosongo, 2011). Siklon tropis ini akan menyebabkan gelombang tinggi dan menyebabkan terganggunya aktivitas pelayaran antara Pulau Pramuka dan Jakarta.

\section{DAFTAR PUSTAKA}

Cahyadi, A. 2012. Permasalahan Sumberdaya Air Pulau Kecil. Prosiding Seminar Lingkungan Hidup 2012. Magister Ilmu Lingkungan, Universitas Diponegoro Semarang.

Cahyadi, A. 2013. Menyelamatkan Masa Depan Pulau Kecil di Indonesia: Sebuah Pembelajaran dari Pulau Pramuka, Kepulauan Seribu. Makalah dalam lomba karya tulis "Potert Indonesia 2014". Moskow: Pimpinan Cabang Istimewa Muhammadiyah Rusia.

Falkland, C. Anthony.1991. Hydrology and Water Resources of Small Island: A Practical Guide. Paris: UNESCO.

Hehanusa, P.E. dan Bakti, Hendra. 2005. Sumber Daya Air di Pulau Kecil. Bandung: LIPI Press.

Marfai, M.A.; Cahyadi, A. dan Poerbandono, R., 2012, Identifikasi Bencana Pesisir dan Kerusakan Lingkungan Di Pulau Pramuka, Provinsi Dki Jakarta. Laporan Penelitian. Magister Perencanaan Pengelolaan Pesisir dan daerah Aliran Sungai Fakultas Geografi Universitas Gadjah Mada Yogyakarta.

Ongkosongo, O.S.R. 2011. Lingkungan Fisik Pulau Pramuka. dalam Ongkosongo, O.S.R.;

Wijonarko, S. dan Afadlal. 2011. Rona Lingkungan Pulau Pramuka. Jakarta: Lembaga Ilmu Pengetahuan Indonesia (LIPI), Pusat Penelitian Oseanografi, Balai Dinamika Laut, Kolompok Penelitian Geologi Laut.

Sumawidjaja, N. dan Suherman, D. 2005a. Ketersediaan Air sebagai Faktor Pembatas Pengambangan Pulau Mangole, Maluku Utara. dalam Hehanusa, P.E. dan Bhakti, Hendra. 2005. (eds) Sumber Daya Air di Pulau Kecil. Bandung: LIPI Press.

Sumawidjaja, N. dan Suherman, D. 2005b. Potensi Sumberdaya Air Sebagai Kendala Pembangunan di Pulau Sulabesi, Maluku Utara. dalam Hehanusa, P.E. dan Bhakti, Hendra. 2005. (eds) Sumber Daya Air di Pulau Kecil. Bandung: LIPI Press. 
Twigg, J. 2004. Disaster Risk Reduction, Mitigation and Preparedness in Development and Emergency Programming, Good Practice Review 9. London: Humanitarian Practice Network.

Twigg, J. 2007. Characteristics of a Disaster-Resilient Community : A Guidance Note. DFID Disaster Risk Reduction Interagency Coordination Group.

Wibowo, P.E. 2010. Identifikasi Perubahan Tutupan Lahan Pulau Panggang, Pulau Pramuka dan Pulau Karya Antara Tahun 2004 dan Tahun 2008. Tugas Akhir. Program Studi Teknik Geodesi dan Geomatika, Fakultas Ilmu dan Teknologi Kebumian, Institut Teknologi Bandung.

Makalah ini merupakan salah satu chapter dalam buku berjudul "Pengelolaan Lingkungan Zamrud Khatulistiwa", dengan Editor Muh Aris Marfai dan M. Widyastuti. Buku ini diterbitkan di Yogyakarta Tahun 2013 oleh Penerbit Pintal. Makalah ini dimuat di halaman 92-98. 